ISSN 1392-3196 / e-ISSN 2335-8947

Zemdirbyste-Agriculture, vol. 103, No. 3 (2016), p. 319-326

DOI 10.13080/z-a.2016.103.041

\title{
Possibilities of using image analysis to estimate the nitrogen nutrition status of apple trees
}

\author{
Waldemar TREDER, Krzysztof KLAMKOWSKI, Waldemar KOWALCZYK, \\ Daniel SAS, Katarzyna WÓJCIK \\ Research Institute of Horticulture \\ Konstytucji 3 Maja 1/3, 96-100 Skierniewice, Poland \\ E-mail: krzysztof.klamkowski@inhort.pl
}

\begin{abstract}
Precise timing and rate of nitrogen (N) fertilizer application play a major role for crop yield and quality. Prediction of $\mathrm{N}$ requirements is necessary for efficient utilization of nitrogen fertilizers. A user-friendly method for estimating foliar nitrogen concentration, based on an analysis of leaf blade colour, was developed in the study. Apple tree (Malus domestica Borkh.) was used as a model species for the validation of the proposed method. Digital recording of adaxial leaf surface was performed using a flatbed scanner. The acquired images were analysed to obtain average values of basic colours: red, green and blue (RGB). Analyses of the relationships between $\mathrm{N}$ concentration in the leaves, leaf greenness indices (determined with SPAD-502 and CCM-200 meters) and RGB colour components were performed. The best fitted models were: a multiple regression model based on RGB primary colour values and a model that included the values of the red and blue colours as well as a parameter describing the age of the leaf. The performed tests showed that the analysis of scanned images provided a more precise determination of leaf nitrogen content in apple trees compared to the measurements conducted with leaf greenness meters.
\end{abstract}

Key words: chlorophyll content, fertilization, plant nutrition, precision horticulture.

\section{Introduction}

Nitrogen $(\mathrm{N})$ is one of the most important mineral nutrients for plant growth, yield and crop quality. Precise timing and rate of $\mathrm{N}$ fertilizer application play a major role in plant nutrition. Prediction of $\mathrm{N}$ requirements is necessary for efficient utilization of nitrogen fertilizers. Improving the efficiency of $\mathrm{N}$ fertilizer utilization reduces the amount of $\mathrm{N}$ that can potentially contaminate soil and water resources. A fertilizer should be applied only after determining that it will be beneficial. Traditionally, plant nutrient status has been measured using a combination of soil and leaf analyses. In agricultural practice, due to the high mobility of nitrates in the soil, nitrogen fertilization is based on leaf appearance or leaf tissue analysis (Kłossowski, 1972; Munson, 1998).

There are two classes of techniques for foliar analysis of nitrogen content: destructive and nondestructive. Laboratory procedures are accurate but destructive and cost and time consuming (Benitez Ramirez, 2010). Non-destructive methods are based on analyses of leaf blade colour and absorbed or reflected light. Leaf colour is a good indicator of plant health and nutrition status. The green colour of plant canopies is associated with leaf chlorophyll content, which is positively correlated with leaf $\mathrm{N}$ concentration (Wolfe et al., 1988). Vigorous vegetative growth and dark green leaves are characteristics of plants with an adequate $\mathrm{N}$ supply, as up to $75 \%$ of nitrogen in mesophyll cells can be located in the chloroplasts (Peoples, Dalling, 1988). The amount of solar radiation absorbed by a leaf is a function of the photosynthetic pigment content. Thus, leaf chlorophyll content is a key indicator of plant physiological status, linked directly to photosynthetic potential and primary production (Filella et al., 1995). One of the results of nitrogen deficiency is lack of chlorophyll formation and a low chlorophyll density in plant leaves. Nitrogen deficiency markedly reduces chlorophyll and carotenoid concentrations within the leaves and changes their colour (Boussadia et al., 2010; Khavari-Nejad et al., 2013). Leaf chlorophyll content, which is correlated with leaf nitrogen concentration, may serve as a method of predicting plant N requirements (Baret, Fourty, 1997; Ali et al., 2012 b).

A number of non-destructive, indirect methods for determining foliar nitrogen content are available, which vary in complexity and optimality. These include the use of a leaf colour chart (LCC) (Furuya, 1987) and portable leaf greenness meters (e.g., SPAD-502, CCM200 and Dualex 4) (Zhang et al., 2009; Ali et al., 2012 b; Cerovic et al., 2015). Non-destructive techniques also include leaf reflectance measurements. In the visible and near-infrared wavelength domain the reflectance properties are mainly governed by the amount of biomass per unit area and the leaf chlorophyll content (Buscaglia, Varco, 2002; Gitelson et al., 2003). 
The nitrogen content in the leaves can also be determined by analysing the distribution of colour components of the image of a single leaf or group of plants (Kawashima, Nakatan, 1998; Mercado-Luna et al., 2010; Rorie et al., 2011; Yuzhu et al., 2011; Wang et al., 2014). The aim of the study was to evaluate whether the concentration of nitrogen in apple trees leaves could be reliably estimated with an image analysis method using a flatbed scanner.

\section{Materials and methods}

Plant material and growing conditions. The study was conducted in 2015 at the Research Institute of Horticulture in Skierniewice, Poland. Two-year-old 'Ligol' apple trees (Malus domestica Borkh.) grafted on $\mathrm{P} 14$ rootstock were planted into $12 \mathrm{~L}$ containers filled with a 3:1 mixture of peat and coco fibre. To accelerate plant growth, the apple trees were cultivated under greenhouse conditions till 15 May. To vary the level of $\mathrm{N}$ nutrition, three fertilization treatments were applied: 1) trees supplied with water only (without fertilization), 2) trees supplied with Rosasol 18:18:28 fertilizer (1 g of fertilizer per $1 \mathrm{~L}$ of water per week) and 3) trees supplied with Rosasol 18:18:28 fertilizer (2 g of fertilizer per $1 \mathrm{~L}$ of water per week).

Leafgreenness measurements. Leafsamples were collected from April to September. During each sampling event, several fully developed leaves on annual shoots were taken from each fertilization treatment. Immediately after sampling, measurements of the greenness level were performed using SPAD-502 (Minolta, Japan) and CCM200 (Opti-Sciences, USA) meters. Three measurements were taken in the middle part of each leaf, and the obtained results were averaged. Digital recording of adaxial leaf surface was also performed using an Epson Perfection 3170 PHOTO scanner (Seiko Epson Corporation, Japan). The leaves were scanned against a black background at 300 DPI. Images were saved as JPEG (joint photographic experts group) files. The acquired images were analysed to obtain average values of basic colours: red, green and blue (RGB).

Determination of total nitrogen content. Chemical analyses were performed on the same leaves that had been used for greenness measurements described above. The plant material, after drying and determining the dry weight by the drier oven method, was mineralized in concentrated sulphuric acid in the presence of a copperpotassium catalyst. The nitrogen content was determined by using the Kjeldahl apparatus VAPODEST (Gerhardt $\mathrm{GmbH}$, Germany). After distillation of nitrogen in the form of $\mathrm{NH}_{3}$, the $\mathrm{N}$ content was determined by titration (Official Methods of Analysis..., 2012).

Image analysis and leaf colour evaluation. A dedicated application was created that determines the colour component values individually for each pixel of leaf image without the background. A threshold was established (RGB values below 30 corresponding to a dark, blackish colour) to distinguish leaf blade colours from the background. To build the application, programming tools Hypertext Preprocessor (PHP, Zend Technologies), HyperText Markup Language (HTML,
W3C \& WHATWG), Cascading Style Sheets (CSS, Håkon Wium Lie, Bert Bos, World Wide Web Consortium), Java Script (Netscape Communications Corporation, Mozilla Foundation, Ecma International) and Jquery (jQuery Team) were used. To generate and analyse graphics in PHP, the appropriate Graphics Library (GD, Thomas Boutell) was applied. This library provides a number of functions for creating and manipulating graphics. The application uses the functions: "imagecreatefromjpeg", "imagecolourat" and "imagecoloursforindex".

Regression analyses were performed to find the relationship between the nitrogen content in apple trees leaves, the indices of leaf greenness and parameters of leaf colour evaluation. Correlation $(r)$ and determination $\left(R^{2}\right)$ coefficients were computed to measure the strength of the relationship between these variables. The standard error (SE) of the mean was calculated and used to indicate error ranges on the graph describing changes in leaf greenness indices, RGB colour components and the concentration of nitrogen during the growing season. Statistical analyses were performed using a software package Statistica (StatSoft Inc., USA).

\section{Results and discussion}

To obtain a reliable assessment of the correlation of the measured parameters with the nitrogen content in the leaves, all the measurements, as well as the analyses, were performed separately for individual leaves. This was possible after a preliminary chemical analysis of a small sample (half of one leaf). The initial analyses were performed on five coded samples (Table 1). The results of these chemical analyses showed a high level of reproducibility allowing further measurements on individual leaves.

Table 1. Nitrogen content (\% dry weigh) in leaf samples

\begin{tabular}{|c|c|c|c|c|}
\hline \multirow{2}{*}{$\begin{array}{c}\text { Sample } \\
\text { No. }\end{array}$} & \multicolumn{2}{|c|}{$\begin{array}{c}\text { Sample } \\
\text { (half of a leaf) }\end{array}$} & \multirow{2}{*}{$\begin{array}{l}\text { Difference } \\
(B-A)\end{array}$} & \multirow{2}{*}{$\begin{array}{c}\text { Difference with } \\
\text { respect to } \\
\text { an average for } \\
\text { A and B samples \% }\end{array}$} \\
\hline & A & B & & \\
\hline 1 & 2.53 & 2.53 & 0 & 0 \\
\hline 2 & 2.89 & 2.91 & 0.02 & 0.69 \\
\hline 3 & 2.65 & 2.77 & 0.12 & 4.43 \\
\hline 4 & 3.31 & 3.35 & 0.04 & 1.20 \\
\hline 5 & 2.50 & 2.56 & 0.06 & 2.37 \\
\hline Average & 2.78 & 2.82 & 0.04 & 1.43 \\
\hline
\end{tabular}

Regression analyses of the measurements conducted with the chlorophyll meters and the chemical analyses confirmed the possibility of using either of the two meters for estimating the nitrogen content in the leaves. For most leaf sampling dates, a highly significant correlation between the nitrogen content and the SPAD and CCM indices (SPAD-502 and CCM-200 readings) was demonstrated (Fig. 1). Significant correlations between SPAD or CCM readings and leaf $\mathrm{N}$ concentration have also been presented by Wang et al. (2014) on rice and by Ghasemi et al. (2011) on Asian pear. In our study, the highest correlation coefficients between the analysed 
parameters were shown for the first two dates of leaf sampling and the lowest for the last date. The parameters determined for the models of linear regression differed significantly between the dates of leaf sampling. This means that if the estimation of the nitrogen content is needed throughout the entire growing period, calibration should be performed several times during the growing season. Depending on the requirements, the right model can be applied for the consecutive phases of the growing season, or a model that takes into account the passage of time during the growing season can be developed on the basis of the combined data. This is confirmed by the results of Neilsen et al. (1995), Chang and Robison (2003) and Treder and Cieśliński (2003) showing that SPAD readings depend on the cultivar and/or time of sampling, and therefore must be standardized for these parameters.
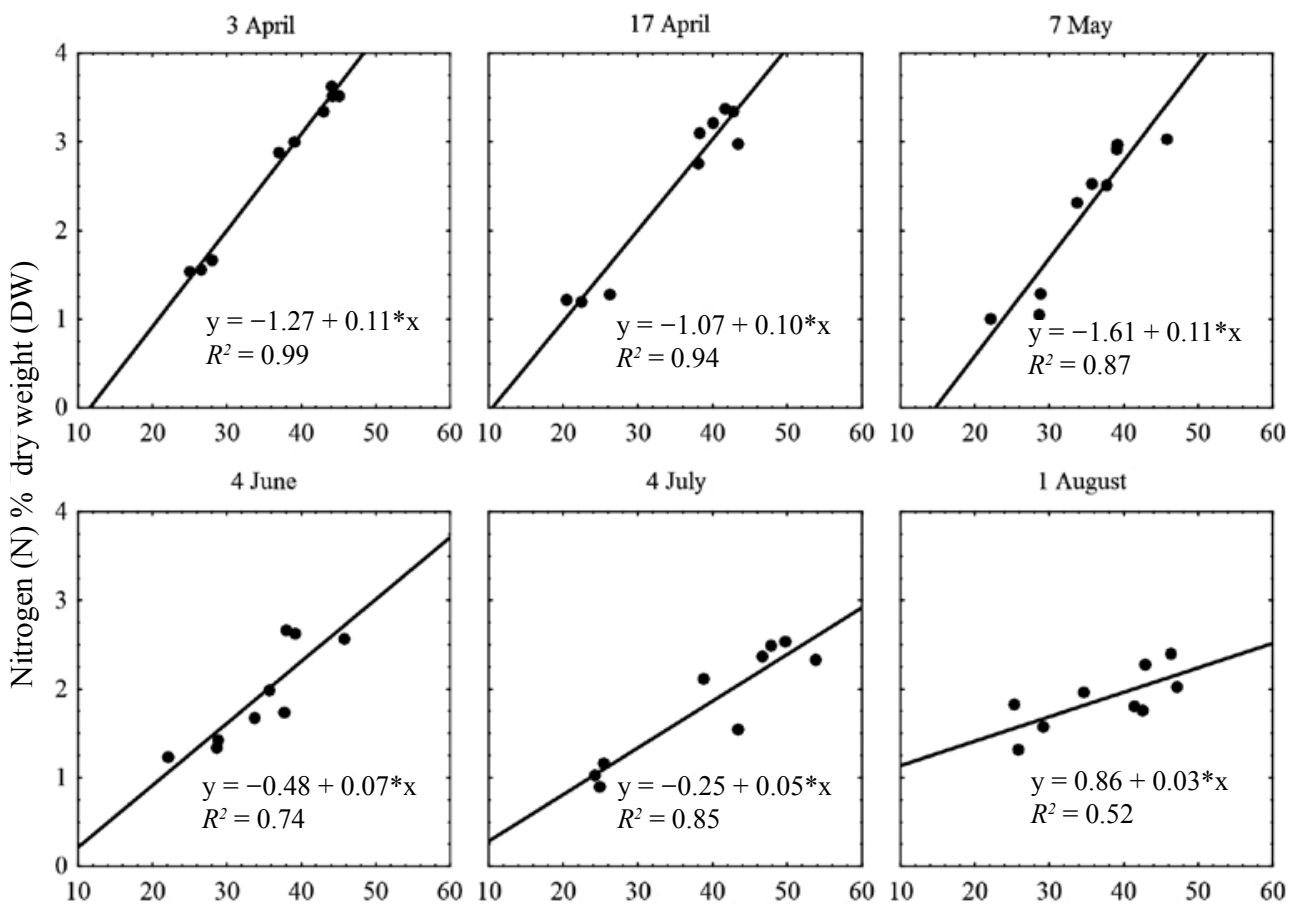

SPAD-502 index
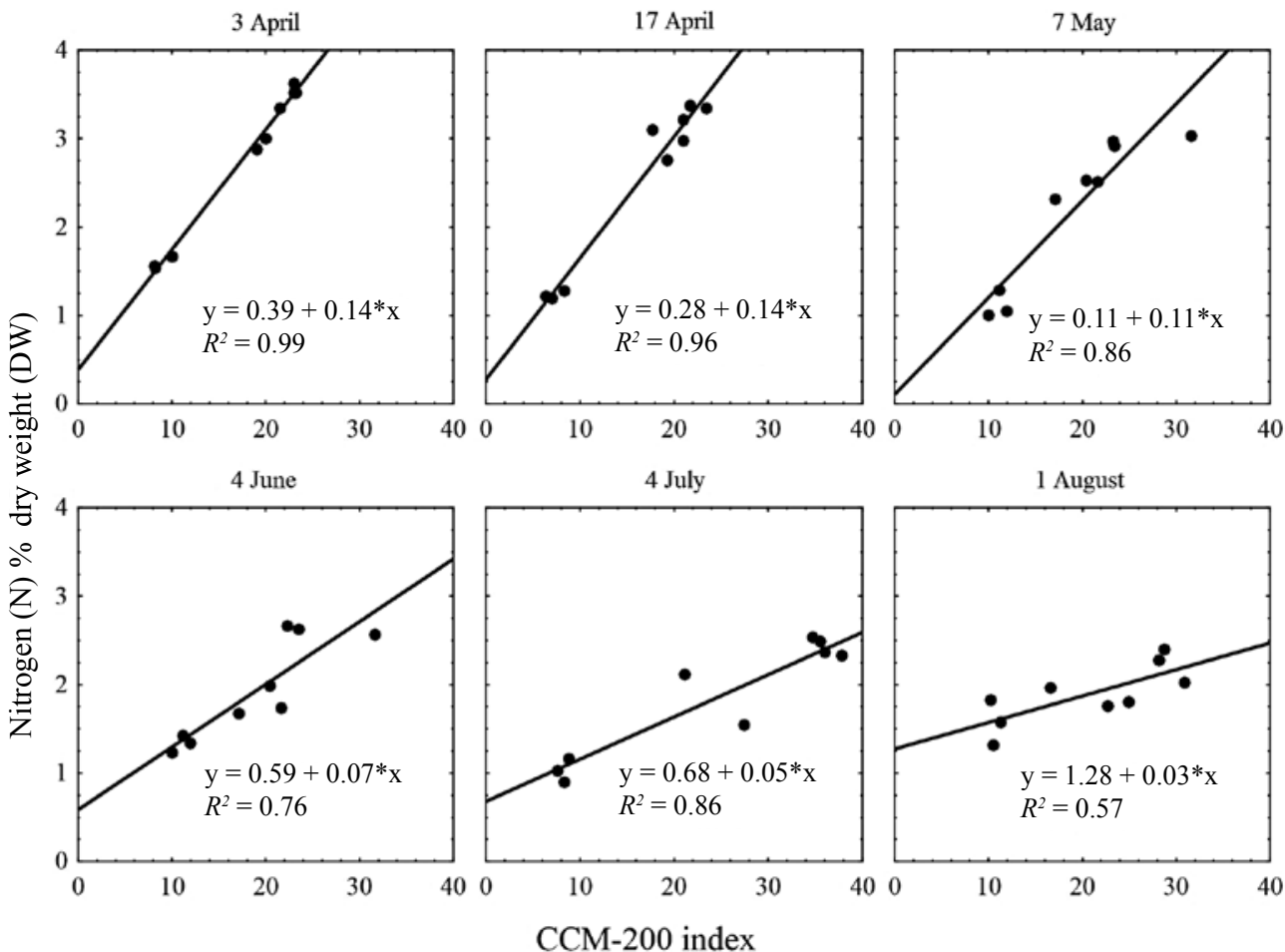

Figure 1. Relationship between SPAD and CCM indices and nitrogen $(\mathrm{N})$ content in apple trees leaves on successive sampling dates 
The study showed the possibility of using image analysis to estimate the nitrogen content in the leaves. A high degree of correlation with the nitrogen content in apple trees leaves was observed for the average values of the red and green components of colour, calculated for the whole leaf area (Fig. 2). Significantly lower correlation with the concentration of nitrogen in the leaves was found for the blue colour component (data not presented). Analysis of digital images of corn fields by
Blackmer et al. (1996) also indicated that the correlation with the nitrogen content in the leaves of plants was the strongest for the red colour and the lowest for the blue colour. Also in the research of Mercado-Luna et al. (2010) describing experiments on tomato, the highest level of correlation between the nitrogen content in the leaves and a colour component of a digital image was shown for the red colour.
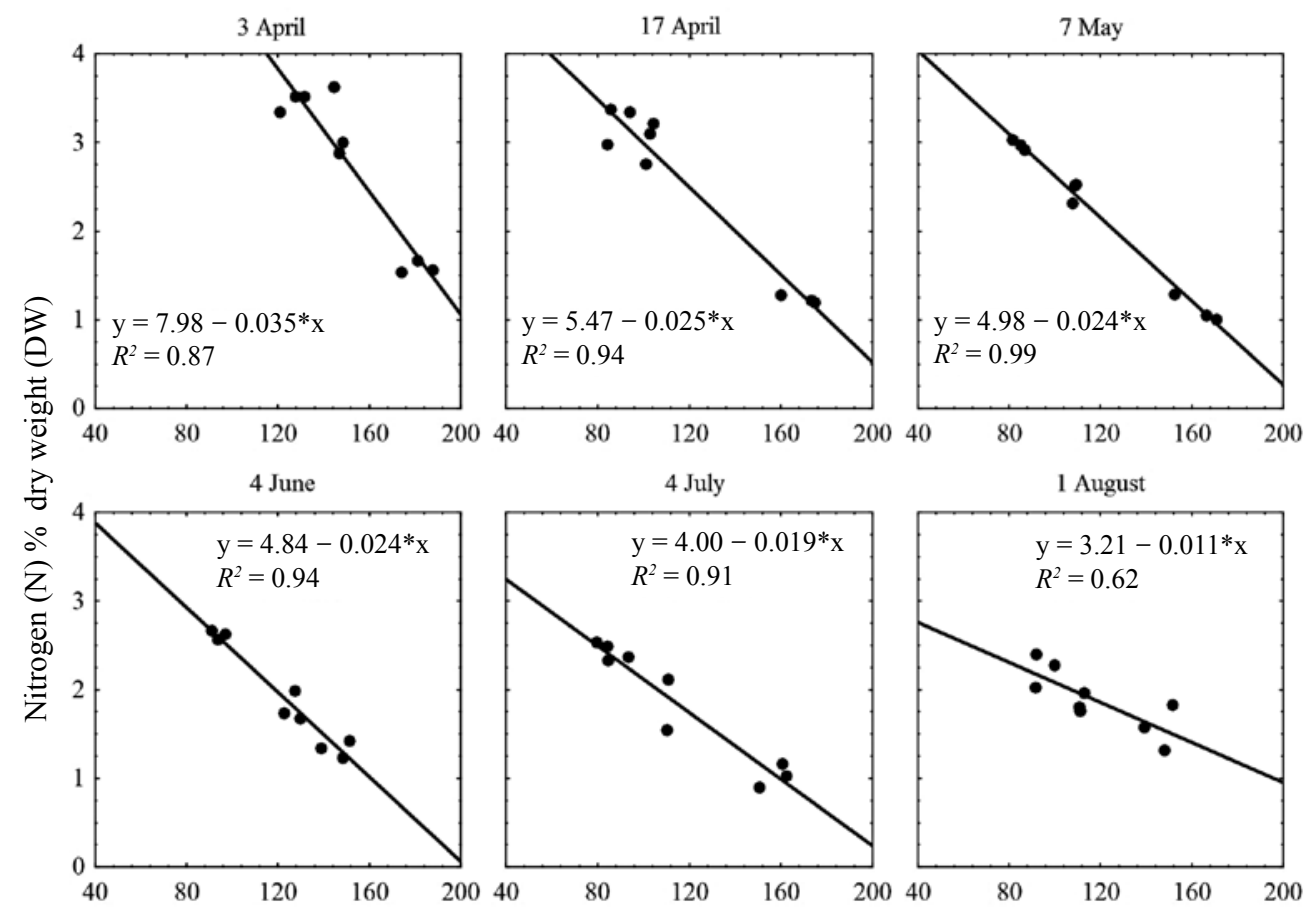

Green
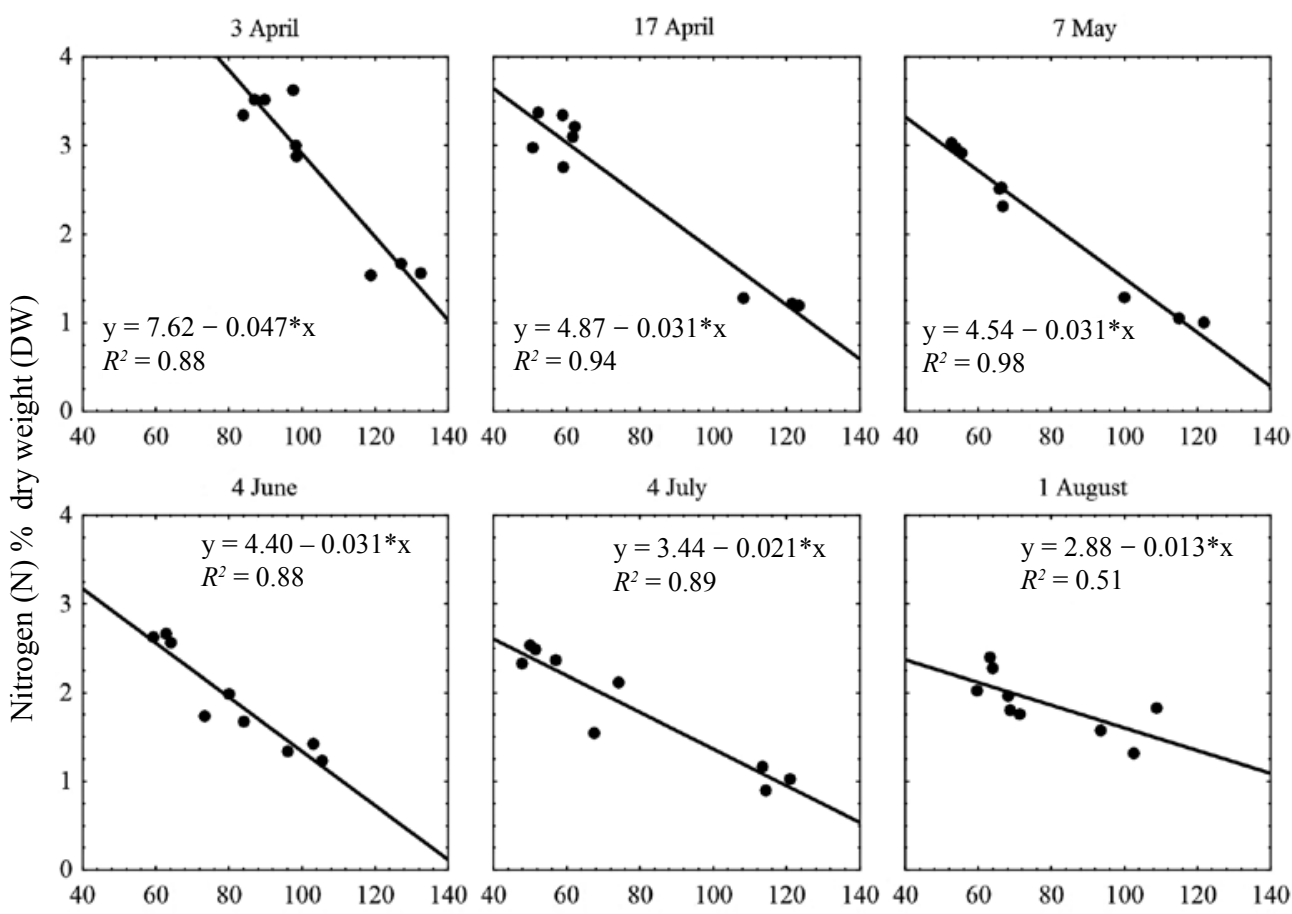

Red

Figure 2. Relationship between the average values of the red and green colours and nitrogen (N) content in apple trees leaves on successive sampling dates 
As with the models developed for chlorophyll meters, the determined models of linear regression between red, green or blue colours and the nitrogen content in the leaves of apple trees varied significantly between the dates of leaf sampling. The reason for this was the decline in nitrogen content in the leaves during the growing season (Fig. 3). The RGB values dropped significantly only in the early stages (between 3 and 17 April) and remained relatively stable for the remainder of the period. The increase in SPAD and CCM values observed in the late part of the growing season may have been caused by changing conditions for the light passing through the leaf - accumulation of dirt, changes in cuticle thickness (Treder, Cieśliński, 2003).
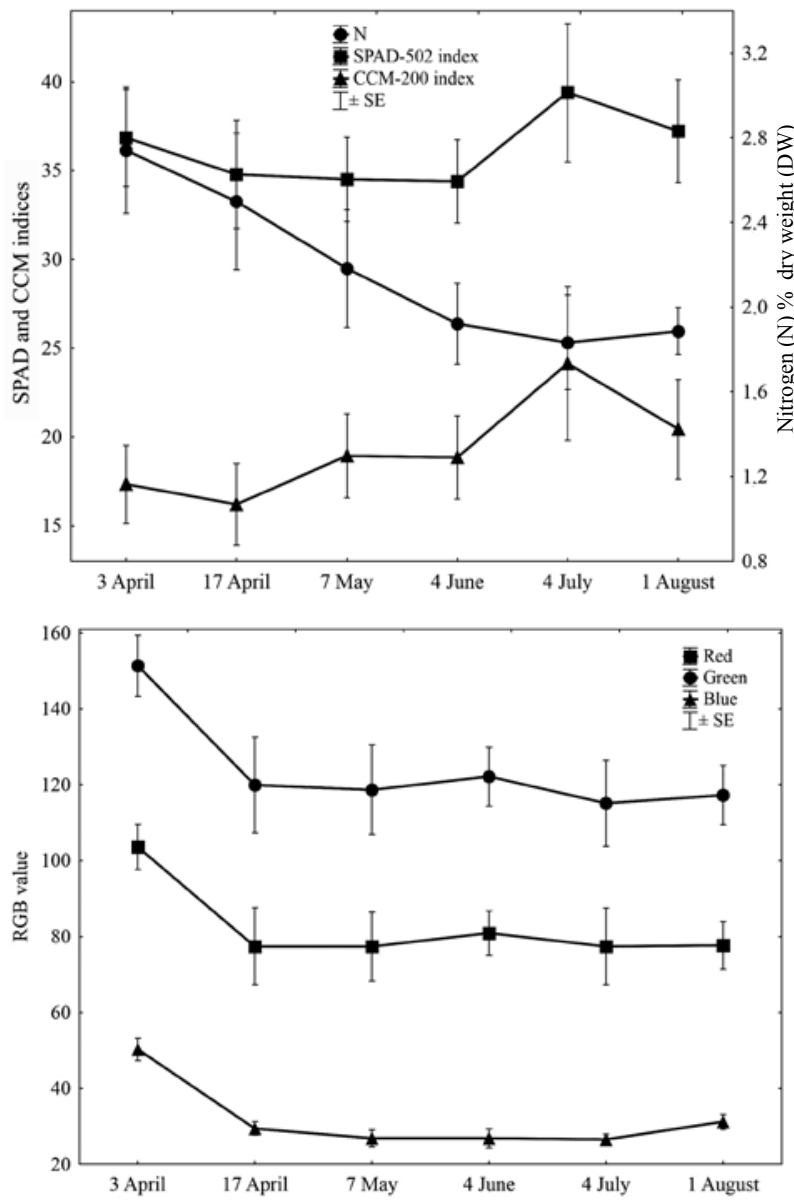

Figure 3. Changes in SPAD and CCM indices, basic colours: red, green and blue (RGB) components and the concentration of nitrogen $(\mathrm{N})$ in the leaves of apple trees on different dates of determination

Table 2 presents the correlation coefficients between the nitrogen content in the leaves of apple trees and indices of chlorophyll content and various RGB formulas. In the early stages, very high correlation coefficients between the nitrogen content in the leaves of apple trees were recorded for the SPAD and CCM indices. Over the course of the season and the aging of leaves, the highest correlation coefficients were shown for $(\mathrm{R}-\mathrm{B})$ and $(\mathrm{G}-\mathrm{B})$ formulas. However, taking into consideration the combined data from all the dates of the evaluation, the $(\mathrm{R}-\mathrm{B}) /(\mathrm{R}+\mathrm{G}+\mathrm{B})$ formula gave the highest level of correlation with the leaf nitrogen content.
A multiple regression analysis taking into account the age of the leaf was used to develop a model for accurate estimation of the nitrogen content in the leaves of apple trees throughout the growing period (Table 3). The age of the leaf was expressed as the number of days counted from the moment of its full development. Introduction of this parameter into the model clearly raised the level of data correlation. For example, the determination coefficient (for the results for the whole growing season) between the measurements of the SPAD index and the nitrogen content in the leaves was $R^{2}=0.55(r=0.74)$ (Table 2). In contrast, when the leaf age parameter was added to the model, its value raised the coefficient to $R^{2}=0.77$ (Table 3 ). The highest level of correlation with the nitrogen content in the leaves was obtained with the model that took into account not only the age of the leaves but also the values of the red and blue colours $\left(R^{2}=0.91\right)$. When the leaf age parameter was omitted, the highest correlation was observed for the multiple regression model that included all three colour components $\mathrm{R}, \mathrm{G}$ and $\mathrm{B}\left(R^{2}=0.84\right)$. The high correlation values obtained by this approach mean that the nitrogen content in the leaves can be reliably determined on the basis of image analysis even when their age is unknown. The accuracy of such determination is even higher than that of chlorophyll meters, designed for this purpose. Similar conclusions have been drawn by Mercado-Luna et al. (2010) who stated that the SPAD method was not a reliable way to estimate the $\mathrm{N}$ status in tomato seedlings. Ali et al. (2012 a; 2013) achieved better performance than SPAD in chlorophyll measurements using a leafcolour based algorithm developed for lettuce, broccoli and tomato plants. Greenness indices based on colour component analysis have also been used to evaluate nitrogen status of barley (Pagola et al., 2009). The authors concluded that the capacity of the developed indices to predict nitrogen deficiencies in barley was equal to or even better than that of SPAD meter. Portable chlorophyll meters have limited resolution, and measure only small samples, which precludes their application for leaves with a non-uniform chlorophyll distribution (Spomer et al., 1988). Rorie and co-authors (2011), after analysing images of corn, concluded that digital colour analysis had the potential to be used in the same way as chlorophyll meters, but at a fraction of the cost. Similar conclusions have been drawn by Vibhute and Bodhe (2013) who applied the image analysis method for estimating nitrogen status of grape leaves. Also Yuzhu et al. (2011) demonstrated the usefulness of image analysis and RGB parameters to evaluate the nitrogen content in the leaves of pepper. Because of its own (constant) light source, the scanner makes it possible to obtain the same intensity of colours regardless of the external lighting conditions.

The quality of nitrogen estimation will depend on the precision of calibration. It is also important to remember about the variation occurring between species and cultivars as well as about the influence of the external conditions during plant cultivation. The use of an image processing method requires calibration to be performed separately for each species and cultivar. This issue also affects leaf greenness meters (Chang, Robison, 2003; Bielinis et al., 2015), as the accuracy of such estimation 
Table 2. Correlation coefficients between leaf basic colour parameters: red, green and blue (RGB), SPAD and CCM indices and nitrogen content in apple trees leaves

\begin{tabular}{cccccccc}
\hline Parameter & 3 April & 17 April & 7 May & 4 June & 4 July & 1 August & All data \\
\hline SPAD & 1.0 & 0.97 & 0.93 & 0.86 & 0.92 & 0.72 & 0.74 \\
CCM & 1.0 & 0.98 & 0.93 & 0.87 & 0.93 & 0.76 & 0.62 \\
R & -0.94 & -0.97 & -0.99 & -0.94 & -0.94 & -0.72 & -0.64 \\
G & -0.93 & -0.97 & -1.0 & -0.97 & -0.95 & -0.79 & -0.63 \\
B & 0.88 & 0.64 & 0.78 & 0.66 & 0.03 & -0.71 & 0.61 \\
R/(R+G + B) & -0.95 & -0.96 & -0.97 & -0.97 & -0.96 & -0.79 & -0.87 \\
G/(R+G + B $)$ & -0.85 & -0.66 & -0.76 & -0.63 & -0.13 & -0.70 & -0.62 \\
B/(R+G + B) & 0.91 & 0.91 & 0.93 & 0.87 & 0.96 & 0.85 & 0.86 \\
$\mathrm{R}-\mathrm{G}$ & 0.86 & 0.92 & 0.92 & 0.76 & 0.70 & 0.81 & 0.51 \\
$\mathrm{R}-\mathrm{B}$ & -0.94 & -0.97 & -0.99 & -0.98 & -0.97 & -0.82 & -0.84 \\
$\mathrm{G}-\mathrm{B}$ & -0.93 & -0.97 & -0.99 & -0.96 & -0.97 & -0.84 & -0.80 \\
$(\mathrm{R}-\mathrm{G}) /(\mathrm{R}+\mathrm{G})$ & -0.53 & -0.91 & -0.75 & -0.25 & -0.83 & -0.19 & -0.48 \\
$(\mathrm{R}-\mathrm{B}) /(\mathrm{R}+\mathrm{B})$ & -0.93 & -0.94 & -0.95 & -0.91 & -0.99 & -0.86 & -0.88 \\
$(\mathrm{G}-\mathrm{B}) /(\mathrm{G}+\mathrm{B})$ & -0.91 & -0.91 & -0.92 & -0.85 & -0.97 & -0.85 & -0.85 \\
$(\mathrm{R}-\mathrm{G}) /(\mathrm{R}+\mathrm{G}+\mathrm{B})$ & 0.29 & -0.77 & -0.35 & -0.05 & -0.75 & 0.09 & -0.20 \\
$(\mathrm{R}-\mathrm{B}) /(\mathrm{R}+\mathrm{G}+\mathrm{B})$ & -0.92 & -0.94 & -0.96 & -0.94 & -0.99 & -0.87 & -0.90 \\
$(\mathrm{G}-\mathrm{B}) /(\mathrm{R}+\mathrm{G}+\mathrm{B})$ & -0.89 & -0.96 & -0.88 & -0.79 & -0.81 & -0.81 & -0.80 \\
\hline
\end{tabular}

Table 3. Parameters of multiple regression equations (with the highest level of determination) defining leaf nitrogen content as a function of leaf age, indices of chlorophyll content (SPAD and CCM), and different parameters of leaf basic colours: red, green and blue evaluation

\begin{tabular}{|c|c|c|c|c|}
\hline No. & Parameter & $\begin{array}{l}\text { Regression } \\
\text { coefficient (b) }\end{array}$ & $p$-value & $\begin{array}{l}\text { Determination } \\
\text { coefficient }\left(R^{2}\right)\end{array}$ \\
\hline \multirow{3}{*}{1} & Absolute term & 1.42 & 0.0000 & \multirow{3}{*}{0.68} \\
\hline & CCM-200 & 0.70 & 0.0000 & \\
\hline & Leaf age & -0.010 & 0.0000 & \\
\hline \multirow{3}{*}{2} & Absolute term & 4.70 & 0.0000 & \multirow{3}{*}{0.70} \\
\hline & Red & -0.024 & 0.0000 & \\
\hline & Leaf age & -0.010 & 0.0000 & \\
\hline \multirow{3}{*}{3} & Absolute term & 5.22 & 0.0000 & \multirow{3}{*}{0.73} \\
\hline & Green & -0.020 & 0.0000 & \\
\hline & Leaf age & -0.011 & 0.0000 & \\
\hline \multirow{3}{*}{4} & Absolute term & 0.035 & 0.88 & \multirow{3}{*}{0.77} \\
\hline & SPAD-502 & 0.073 & 0.0000 & \\
\hline & Leaf age & -0.0088 & 0.0000 & \\
\hline \multirow{4}{*}{5} & Absolute term & 1.65 & 0.0000 & \multirow{4}{*}{0.84} \\
\hline & Red & -0.055 & 0.0000 & \\
\hline & Green & 0.028 & 0.0058 & \\
\hline & Blue & 0.052 & 0.0000 & \\
\hline \multirow{4}{*}{6} & Absolute term & 4.05 & 0.0000 & \multirow{4}{*}{0.90} \\
\hline & Red - Blue & -0.016 & 0.0000 & \\
\hline & $\begin{array}{c}(\text { Red }- \text { Blue }) / \\
(\text { Red }+ \text { Blue })\end{array}$ & -1.55 & 0.0106 & \\
\hline & Leaf age & -0.68 & 0.0000 & \\
\hline \multirow{4}{*}{7} & Absolute term & 3.23 & 0.0000 & \multirow{4}{*}{0.91} \\
\hline & Red & -0.023 & 0.0000 & \\
\hline & Blue & -0.038 & 0.0000 & \\
\hline & Leaf age & 0.0063 & 0.0000 & \\
\hline
\end{tabular}

is strongly influenced by leaf anatomical characteristics. Incurring calibration expenses will be economically justifiable only in a situation when multiple estimations of the nitrogen content in plant leaves are performed. To scan a leaf image with a flatbed scanner, it is necessary to detach the leaf from the plant (therefore this is not a non-destructive method). In further research, an attempt will be made to use a hand-held scanner for acquiring leaf images in the field.

\section{Conclusions}

1. In the study, we proposed a new approach to the problem of rapid estimation of leaf nitrogen content. Analysis of scanned images provided a more precise determination of the nitrogen content in apple trees leaves compared to the measurements taken with SPAD502 and CCM-200 meters.

2. The best fitted models for the estimation of nitrogen content in apple trees leaves were: the multiple regression model based on red, green and blue (RGB) primary colour values and the model that included the values of the red and blue colours and the parameter describing the age of the leaf.

3. The obtained results indicate the possibility of a practical application of a scanner to estimate nitrogen content in plant leaves. Quick access to data related to plant nitrogen status can be helpful in rational plant nutrition. Because of the low cost of the scanner such an approach can be an attractive alternative to the currently used optical chlorophyll meters.

4. Another advantage of the proposed method is the possibility of image archiving; such images can be used for comparison in other analyses (e.g., influence of weather conditions, application of new agronomic practices). In future, this method could be implemented in decision support systems for the management of plant nutrition, which would be placed on web pages of companies and agricultural advisory services.

5. The method proposed in this study was successfully tested on apple trees leaves. The method should be calibrated for each species, or even cultivar, to be able to estimate plant $\mathrm{N}$ nutritional status accurately.

Received 10032016 Accepted 06062016 


\section{References}

Ali M. M., Al-Ani A., Eamus D., Tan D. K. Y. 2012 (a). A new image processing based technique to determine chlorophyll in plants. American-Eurasian Journal of Agricultural and Environmental Sciences, 12: 1323-1328

Ali M. M., Al-Ani A., Eamus D., Tan D. K. Y. 2012 (b). Leaf nitrogen determination using handheld meters. Proceedings of $16^{\text {th }}$ Australian Agronomy Conference. Australian Society of Agronomy. <http://www.regional.org.au/au/ asa/2012/precision-agriculture/7979_alim.htm $>$ [accessed 0903 2016]

Ali M. M., Al-Ani A., Eamus D., Tan D. K. Y. 2013. An algorithm based on the RGB colour model to estimate plant chlorophyll and nitrogen contents. Proceedings of International Conference on Sustainable Environment and Agriculture, p. 52-56<http://www.ipcbee.com/vol57/010ICSEA2013-B1014.pdf $>$ [accessed 0903 2016]

Baret F., Fourty T. 1997. Radiometric estimates of nitrogen status of leaves and canopies. Lemaire G. (ed.). Diagnosis of the nitrogen status in crops. Berlin, Heidelberg, p. 201-227 http://dx.doi.org/10.1007/978-3-642-60684-7 12

Benitez Ramirez M. 2010. Monitoring nitrogen levels in the cotton canopy using real-time active-illumination spectral sensing: master's thesis, University of Tennessee, USA $<\mathrm{http}: / /$ trace.tennessee.edu/utk gradthes/604> [accessed 0903 2016]

Bielinis E., Jóźwiak W., Robakowski P. 2015. Modelling of the relationship between the SPAD values and photosynthetic pigments content in Quercus petraea and Prunus serotina leaves. Dendrobiology, 73: 125-134 http://dx.doi.org/10.12657/denbio.073.013

Blackmer T. M., Schepers J.S., Varvel G. E., Meyer G. 1996. Analysis of aerial photography for nitrogen stress within corn fields. Agronomy Journal, 88: 729-733 http://dx.doi.org/10.2134/agronj1996.00021962008800050008x

Boussadia O., Steppe K., Zgallai H., Ben El Hadj S., Braham M., Lemeur R., Van Labeke M. C. 2010. Effects of nitrogen deficiency on leaf photosynthesis, carbohydrate status and biomass production in two olive cultivars 'Meski' and 'Koroneiki'. Scientia Horticulturae, 123: 336-342 http://dx.doi.org/10.1016/j.scienta.2009.09.023

Buscaglia H. J., Varco J. J. 2002. Early detection of cotton leaf nitrogen status using leaf reflectance. Journal of Plant Nutrition, 25: 2067-2080 http://dx.doi.org/10.1081/PLN-120013295

Cerovic Z. G., Ghozlen N. B., Milhade C., Obert M., Debuisson S., Le Moigne M. 2015. Nondestructive diagnostic test for nitrogen nutrition of grapevine (Vitis vinifera L.) based on Dualex leaf-clip measurements in the field. Journal of Agricultural and Food Chemistry, 63: 3669-3680 http://dx.doi.org/10.1021/acs.jafc.5b00304

Chang S. X., Robison D. J. 2003. Nondestructive and rapid estimation of hardwood foliar nitrogen status using the SPAD-502 chlorophyll meter. Forest Ecology and Management, 181: 331-338 http://dx.doi.org/10.1016/S0378-1127(03)00004-5

Filella I., Serrano I., Serra J. Peńuelas J. 1995. Evaluating wheat nitrogen status with canopy reflectance indices and discriminant analysis. Crop Science, 35: 1400-1405 http://dx.doi.org/10.2135/cropsci1995.0011183X003500050023x

Furuya S. 1987. Growth diagnosis of rice plants by means of leaf color. Japan Agricultural Research Quarterly, 20: $147-153$
Ghasemi M., Arzani K., Yadollahi A., Ghasemi S., Sarikhani S. 2011. Estimate of leaf chlorophyll and nitrogen content in Asian pear (Pyrus serotina Rehd.) by CCM-200. Notulae Scientia Biologicae, 3: 91-94

Gitelson A. A., Gritz Y., Merzlyak M. N. 2003. Relationships between leaf chlorophyll content and spectral reflectance and algorithms for non-destructive chlorophyll assessment in higher plant leaves. Journal of Plant Physiology, 160: 271-282

http://dx.doi.org/10.1078/0176-1617-00887

Kawashima S., Nakatan M. 1998. An algorithm for estimating chlorophyll content in leaves using video camera. Annals of Botany, 81: 49-54 http://dx.doi.org/10.1006/anbo.1997.0544

Khavari-Nejad R. A., Najafi F., Tofighi C. 2013. The effects of nitrate and phosphate deficiencies on certain biochemical metabolites in tomato (Lycopersicon esculentum Mill. c.v. Urbana V.F.) plant. Journal of Stress Physiology and Biochemistry, 9 (2): 64-73

Kłossowski W. 1972. Fertilization of fruit crops. Warszawa, Poland (in Polish)

Mercado-Luna A., Rico-Garcia E., Lara-Herrera A., SotoZarazúa G., Ocampo-Velázquez R., Guevara-González R., Herrera-Ruiz G., Torres-Pacheco I. 2010. Nitrogen determination on tomato (Lycopersicon esculentum Mill.) seedlings by color image analysis (RGB). African Journal of Biotechnology, 9: 5326-5332

Munson R. D. 1998. Principles of plant analysis. Kalra Y. P. (ed.). Handbook of methods for plant analysis. Boca Raton, USA, p. 1-24

Neilsen D., Hogue E. J., Neilsen G. H., Parchomchuk P. 1995. Using SPAD-502 values to assess the nitrogen status of apple trees. HortScience, 30: 508-512

Official Methods of Analysis of AOAC INTERNATIONAL. 2012 ( $19^{\text {th }}$ ed.) Official Method 978.04

Pagola M., Ortiz R., Irogoyen I., Bustince H., Barrenechea E., Aparicio-Trejo P., Lamsfus C., Lasa B. 2009. New method to asses barley nitrogen nutrition status based on image colour analysis. Comparison with SPAD-502. Computers and Electronics in Agriculture, 65: 213-218 http://dx.doi.org/10.1016/j.compag.2008.10.003

Peoples M. B., Dalling M. S. 1988. The interplay between proteolysis and amino acid metabolism during senescence and nitrogen reallocation. Nodden L. D., Leopold A. C. (eds). Senescence and aging in plants, San Diego, USA, p. $181-217$ http://dx.doi.org/10.1016/b978-0-12-520920-5.50012-2

Rorie R. L., Purcell L. C., Karcher D. E., King A. C. 2011. The assessment of leaf nitrogen in corn from digital images. Crop Science, 51: 2174-2180 http://dx.doi.org/10.2135/cropsci2010.12.0699

Spomer L. A., Smith M. A. L., Sawwan J. S. 1988. Rapid nondestructive measurement of chlorophyll content in leaves with nonuniform chlorophyll distribution. Photosynthesis Research, 16: 227-284 http://dx.doi.org/10.1007/BF00028845

Treder W., Cieśliński G. 2003. Evaluation of apple nitrogen status using SPAD-502. Folia Horticulturae, supplement 2: 168-170 (in Polish)

Vibhute A., Bodhe S. K. 2013. Color image processing approach for nitrogen estimation of vineyard. International Journal of Agricultural Science and Research, 3 (3): 189-196

Wang Y., Wang D., Shi P., Omasa K. 2014. Estimating rice chlorophyll content and leaf nitrogen concentration with a digital still color camera under natural light. Plant Methods, 10 (1): 36 http://dx.doi.org/10.1186/1746-4811-10-36 
Wolfe D. W., Henderson D. W., Hsiao T. C., Alvino A. 1988. Interactive water and nitrogen effects on senescence of maize. II. Photosynthetic decline and longevity of individual leaves. Agronomy Journal, 80 (6): 865-870 http://dx.doi.org/10.2134/agronj1988.00021962008000060005x

Yuzhu H., Xiaomei W., Shuyao S. 2011. Nitrogen determination in pepper (Capsicum frutescens L.) plants by color image analysis (RGB). African Journal of Biotechnology, 10: $17737-17741$
Zhang X., Yan R., Cao W. J., Shu B., Zhang Y. J. 2009. Rapid selection of white clover germplasms' crude protein traits by SPAD and Fourier transform near-infrared reflectance spectroscopy. Spectroscopy and Spectral Analysis, 29: 2388-2391

ISSN 1392-3196 / e-ISSN 2335-8947

Zemdirbyste-Agriculture, vol. 103, No. 3 (2016), p. 319-326

DOI 10.13080/z-a.2016.103.041

\title{
Vaizdo analizès panaudojimo galimybès vertinant obelų mitybą azotu
}

\author{
W. Treder, K. Klamkowski, W. Kowalczyk, D. Sas, K. Wójcik \\ Lenkijos sodininkystès tyrimų institutas
}

\section{Santrauka}

Augalų derliui ir kokybei didelès įtakos turi tikslus tręšimo azotu laikas ir azoto trąšų norma. Siekiant efektyviai panaudoti azoto trąšas, būtina prognozuoti augalų azoto poreikį. Atliekant tyrimus buvo sukurtas paprastas metodas nustatyti azoto koncentracijai lapuose, remiantis lapalakščio spalva. Tiriant šio modelio tinkamumą kaip modelinè rūšis pasirinkta naminè obelis (Malus domestica Borkh.). Skaitmeninis adaksialinis lapo paviršius buvo registruotas gulsčiu skeneriu. Gauti vaizdai analizuoti siekiant nustatyti pagrindinių spalvų: raudonos, žalios ir mėlynos (RŽM), vertes. Buvo atlikta ryšių tarp azoto koncentracijos lapuose, lapų žalumo indekso (nustatyto taikant SPAD-502 ir CCM-200) ir RŽM spalvų komponentų analizè. Tinkamiausi modeliai buvo šie: kartotinès regresijos modelis, paremtas pagrindinių RŽM spalvų vertèmis, ir modelis, ị kurị buvo ịtrauktos raudonos bei mėlynos spalvų vertès ir lapo amžių apibūdinantys rodikliai. Atlikti tyrimai parodè, kad nuskenuotų vaizdų analizė rodo tikslesnį azoto kiekị obelų lapuose, palyginus su matavimais, atliktais lapų žalumos matavimo prietaisais.

Reikšminiai žodžiai: augalų mityba, chlorofilo kiekis, tikslioji sodininkystè, tręšimas.

Please use the following format when citing the article:

Treder W., Klamkowski K., Kowalczyk W., Sas D., Wójcik K. Possibilities of using image analysis to estimate the nitrogen nutrition status of apple trees. Zemdirbyste-Agriculture, 103 (3): 319-326 DOI 10.13080/za.2016.103.041 